Journal of Oral Science, Vol. 43, No. 3, 165-169, 2001

\title{
Papillary squamous cell carcinoma of the oral mucosa: immunohistochemical comparison with other carcinomas of oral mucosal origin
}

\author{
Yasunori Takeda, Masanobu Satoh, Shin-ichi Nakamura ${ }^{\S}$ and Hirotsugu Yamamoto ${ }^{\dagger}$ \\ Department of Oral Pathology, School of Dentistry and ${ }^{\S}$ Division of Clinical Pathology, Iwate Medical \\ University, Iwate 020-8505
}

${ }^{\dagger}$ Department of Pathology, Nihon University School of Dentistry at Matsudo, Chiba 271-8587

(Received 12 April and accepted 19 June 2001)

\begin{abstract}
Papillary squamous cell carcinoma (PSCC) is a poorly described variant of squamous cell carcinoma, and may be confused with verrucous carcinoma of the head and neck. To add to existing knowledge of this rare tumor, we describe two cases of PSCC arising in the oral mucosa. The lesions were composed of exophytic proliferation of atypical to overtly malignant cells similar to those of conventional squamous cell carcinoma, and invasion into the superficial region of the underlying fibrous tissue was seen in the form of islands and cords of malignant cells. Immunohistochemical assessment of cellular proliferative activity showed a significantly high mean percentage of Ki-67 expression in comparison with verrucous carcinoma, but there was no significant difference of $\mathrm{Ki}-67$ expression among PSCC, conventional squamous cell carcinoma and microinvasive squamous cell carcinoma. These results suggest that the biological behavior of PSCC is analogous to that of SCC. (J. Oral Sci. 43, 165-169, 2001)
\end{abstract}

Key words: papillary squamous cell carcinoma; oral carcinoma; proliferative activity; Ki-67.

\section{Introduction}

Papillary squamous cell carcinoma (PSCC), a recently

Correspondence to Dr. Yasunori Takeda, Department of Oral Pathology, School of Dentistry, Iwate Medical University, 191 Uchimaru, Morioka, Iwate 020-8505, Japan

Tel: +81-19-651-5111 ext. 3521 Fax: +81-19-621-3321

E-mail address: ytakeda@iwate-med.ac.jp described but poorly documented variant of squamous cell carcinoma, appears macroscopically as an exophytic papillary proliferation, but microscopically is composed of papillae covered by overtly malignant squamous cells (1-3). PSCC may be completely exophytic (PSCC in situ or noninvasive PSCC), but often there is an underlying component of nonpapillary, invasive squamous cell carcinoma (PSCC or invasive PSCC). The small numbers of reported cases of PSCC have shown a male predilection, and the site of involvement is the upper aerodigestive tract (4-6). PSCC should not be confused with verrucous carcinoma or conventional squamous cell carcinoma, not only in terms of pathology but also clinical features and treatment modalities.

To our knowledge, only four papers documenting the clinical and pathological features of PSCC have appeared in the English literature (4-7), and few investigations have described the biological differences between PSCC and other types of squamous cell carcinoma at the molecular level or in terms of cellular proliferative activity. The present communication reports the histopathological features of two cases of PSCC arising in the oral mucosa, and attempts to clarify the different patterns of immunohistochemical expression of Ki-67 among PSCC, conventional squamous cell carcinoma, microinvasive squamous cell carcinoma and verrucous carcinoma in order to add to existing knowledge of this tumor.

\section{Clinical Summary}

Case 1 was a tumor in the oral floor of a 68-year-old, edentulous Japanese man who had been aware of the mass for four months. Clinical examination revealed a well circumscribed, erythematous, papillary tumor mass 
measuring $12 \times 8 \times 5 \mathrm{~mm}$ on the left side of the oral floor. The tumor was mobile and elastic soft in consistency. No regional lymph nodes were palpable. The lesion was clinically diagnosed as a probable benign tumor of the oral floor, and surgical resection was performed under local anesthesia. The healing process was normal without any signs of recurrence.

Case 2 was a tumor in the soft palate of a 72-year-old Japanese man who had been aware of the mass for three months. The clinical features of the tumor, which measured $8 \times 6 \times 4 \mathrm{~mm}$, were similar to those of case 1 . There was no cervical lymphadenopathy. The clinical diagnosis was a probable benign tumor of the soft palate, and surgical resection was performed. The healing process was normal without any signs of recurrence.

\section{Materials and Methods}

The surgically resected specimens were fixed in $10 \%$ neutral-buffered formalin and embedded in paraffin by the routine procedure. In addition to hematoxylin-eosin staining for histopathological examination, sections were used for Ki-67 immunostaining by the streptavidin-biotin method (Histofine SAB-PO kit; BioGenex Labs, Dublin, CA, USA). The Ki-67 antibody (diluted 1:50) was Ki-67 mouse monoclonal antibody MIB-1 (Immunotech SA, Marseilles, France). Negative controls for immunostaining were created by replacing the primary antibody with phosphatebuffered saline.

Four cases of conventional well differentiated squamous cell carcinoma (SCC), two cases of microinvasive squamous cell carcinoma (MSCC), and three cases of verrucous carcinoma (VC) were selected to match the age (seventh to eighth decade), sex (male) and tumor size (under $15 \mathrm{~mm}$ in greatest diameter) of the patients with PSCC, and served as comparative specimens (Table 1).

Ki-67-positive cells were defined as cells with clear brown staining in the nuclei. For each case, the mean percentage of positively stained cells was estimated by counting 500 cells per area from at least five randomly selected areas representative of the lesion's histology. Data were expressed as the mean percentage of positive cells $\pm 95 \%$ confidence intervals. The Wilcoxon test and KruskalWallis $\mathrm{H}$-test were used to investigate the statistical significance of differences in Ki-67 expression among the specimen groups.

Table 1 Materials examined and their immunohistochemical quantitative results for Ki-67 expression

\begin{tabular}{|c|c|c|c|c|}
\hline Diagnosis & Age & Sex & Site & $\mathrm{Ki}-67^{*}$ \\
\hline PSCC & $\begin{array}{l}68 \\
72\end{array}$ & $\begin{array}{l}\text { male } \\
\text { male }\end{array}$ & $\begin{array}{l}\text { mouth floor } \\
\text { soft palate }\end{array}$ & $\begin{array}{l}59.0 \pm 12.1 \\
53.2 \pm 13.0\end{array}$ \\
\hline SCC & $\begin{array}{l}66 \\
67 \\
73 \\
73\end{array}$ & $\begin{array}{l}\text { male } \\
\text { male } \\
\text { male } \\
\text { male }\end{array}$ & $\begin{array}{l}\text { oropharynx } \\
\text { tongue } \\
\text { tongue } \\
\text { mouth floor }\end{array}$ & $\begin{array}{l}63.0 \pm 6.4 \\
56.7 \pm 7.1 \\
70.4 \pm 12.3 \\
69.0 \pm 12.0\end{array}$ \\
\hline MSCC & $\begin{array}{l}64 \\
70\end{array}$ & $\begin{array}{l}\text { male } \\
\text { male }\end{array}$ & $\begin{array}{l}\text { tongue } \\
\text { mouth floor }\end{array}$ & $\begin{array}{l}46.1 \pm 7.2 \\
52.2 \pm 11.8\end{array}$ \\
\hline VC & $\begin{array}{l}65 \\
65 \\
77\end{array}$ & $\begin{array}{l}\text { male } \\
\text { male } \\
\text { male }\end{array}$ & $\begin{array}{l}\text { gingiva } \\
\text { gingiva } \\
\text { buccal mucosa }\end{array}$ & $\begin{array}{l}28.9 \pm 10.1 \\
24.6 \pm 9.2 \\
30.6 \pm 9.5\end{array}$ \\
\hline
\end{tabular}

PSCC, papillary squamous cell carcinoma; SCC, conventinal squamous cell carcinoma; MSCC, microinvasive squamous cell carcinoma; VC, verrucous carcinoma.

${ }^{*}$ Results are expressed as the percentage of positive cells $\pm 95 \%$ confidence intervals. 


\section{Results \\ Histopathological findings}

The lesion of case 1 consisted of an exophytic proliferation of squamous epithelial cells covering papillae with a fibrovascular narrow stroma (Fig. 1a). The epithelium varied in thickness. The papillae lacked abundant surface keratinization (Fig. 1b), and were composed of atypical to overtly malignant cells similar to those of conventional squamous cell carcinoma (Fig. 1c). Invasion into the superficial region of underlying fibrous tissue was seen in the form of islands and cords of malignant cells (Fig. 1d). Furthermore, infiltrating carcinoma involved the minor salivary gland duct epithelium. Diffuse infiltration of small mononuclear cells was seen in the underlying fibrous tissue.

The histopathological features of case 2 were similar to those of case 1, but the lesion was surrounded by a wide zone of non-papillary and non-invasive squamous cell carcinoma (Fig. 2a), and individual cell keratinization was partially evident (Fig. 2b).

\section{Immunohistochemical findings}

Ki-67-positive cells were scattered haphazardly throughout the cancer nests of PSCC and SCC (Figs. 3a,b). In MSCC, Ki-67-positive cells were demonstrated in the infiltrating cancer nests and lower half of the thickened epithelium with malignant characteristics (Fig. 3c). Only basally and parabasally located cells were positive for Ki-67 in VC (Fig. 3d).

Quantitative immunohistochemical results are summarized in Table 1. Ki-67-positive cells accounted for $53.2-59.0 \%$ in PSCC, $56.7-70.4 \%$ in SCC, $46.1-52.2 \%$ in MSCC and $24.6-30.6 \%$ in VC, and the frequency of Ki67-positive cells was significantly low in $\mathrm{VC}$ when compared to PSCC, SCC and MSCC ( $\mathrm{P}<0.001)$; there were no statistical significances in $\mathrm{Ki}-67$ expression among PSCC, SCC and MSCC.
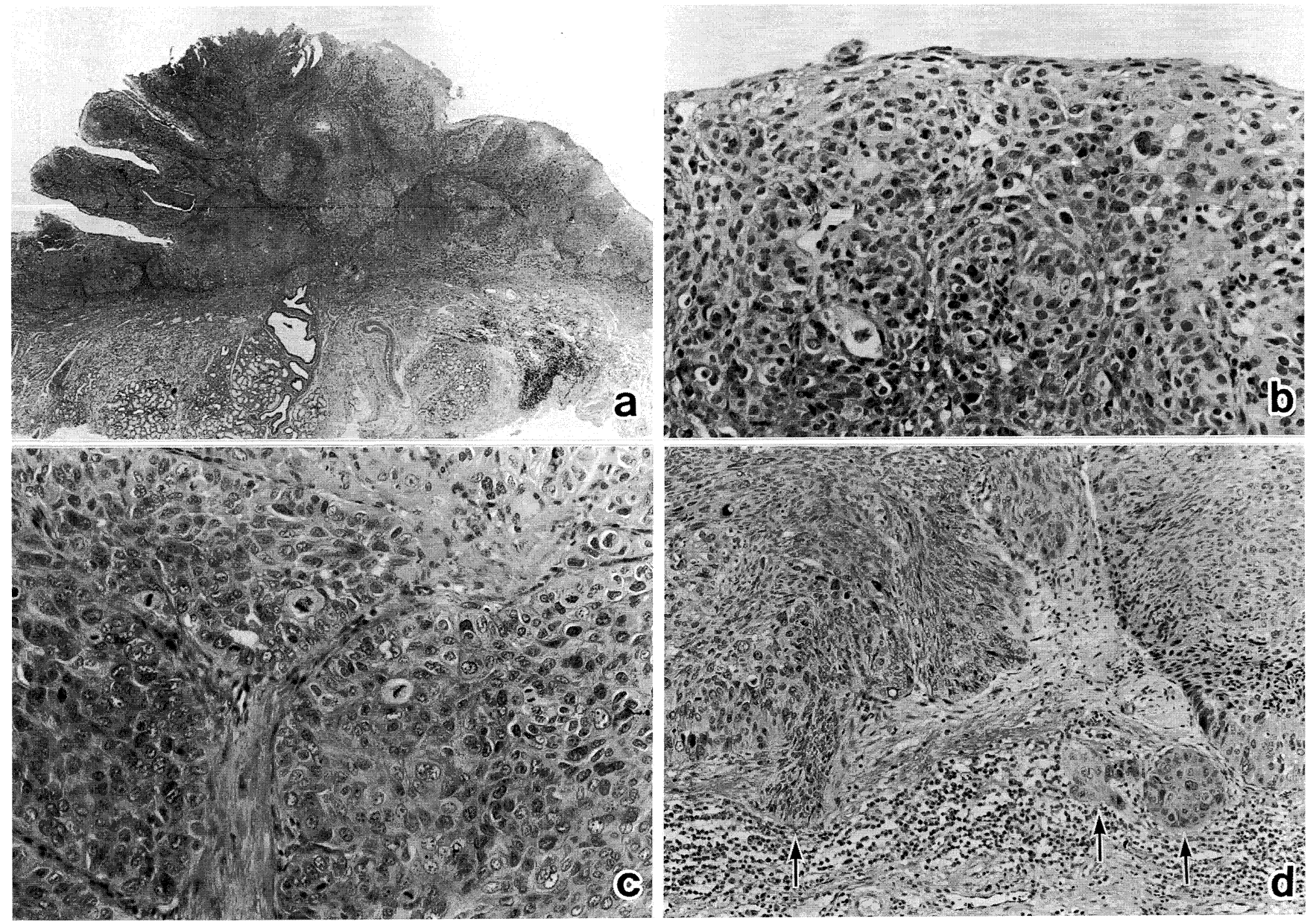

Fig. 1 Papillary squamous cell carcinoma of case 1. (a) An exophytic proliferation of squamous epithelium varies in thickness $(\mathrm{HE}, \times 8)$. (b) The papillae lack abundant surface keratinization $(\mathrm{HE}, \times 100)$. (c) Proliferating squamous cells show atypical to overtly malignant features similar to those of conventional squamous cell carcinoma (HE, $\times 300)$. (d) Invasion into the superficial region of the underlying fibrous tissue in the form of islands and cords of malignant cells (arrows; HE, $\times 40$ ). 


\section{Discussion}

PSCC is a variant of squamous cell carcinoma and may present as either an in situ or invasive tumor. It occurs most frequently in male patients from 50 to 70 years of age, and the most common site is the larynx, followed by the oropharynx and nasopharynx $(4,6)$. PSCC may be completely exophytic, but often there is an underlying component of non-papillary, invasive squamous cell carcinoma. Although the natural history of the non-invasive form of PSCC is unclear, some investigators have suggested that the rate of transformation to an invasive lesion is high (4).

Clinically, both PSCC and VC appear as an exophytic, papillary tumor, but the latter is white, warty and fungating with multiple filiform projections. Careful histopathological investigation is needed to establish the correct diagnosis, which is essential for appropriate treatment (3-7). VCs containing areas that are indistinguishable from SCC have
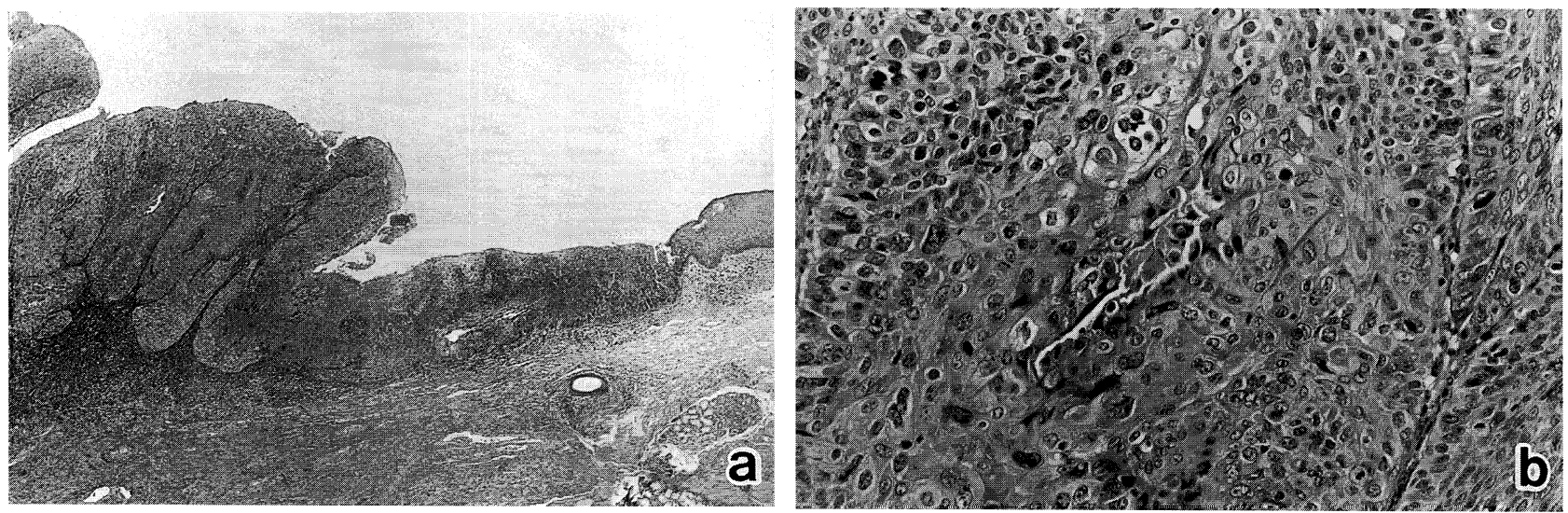

Fig. 2 Papillary squamous cell carcinoma of case 2. (a) A wide zone of non-papillary and non-invasive squamous cell carcinoma surrounds the exophytic papillary lesion $(\mathrm{HE}, \times 10)$. (b) Partially evidence of individual cell keratinization $(\mathrm{HE}, \times 250)$.

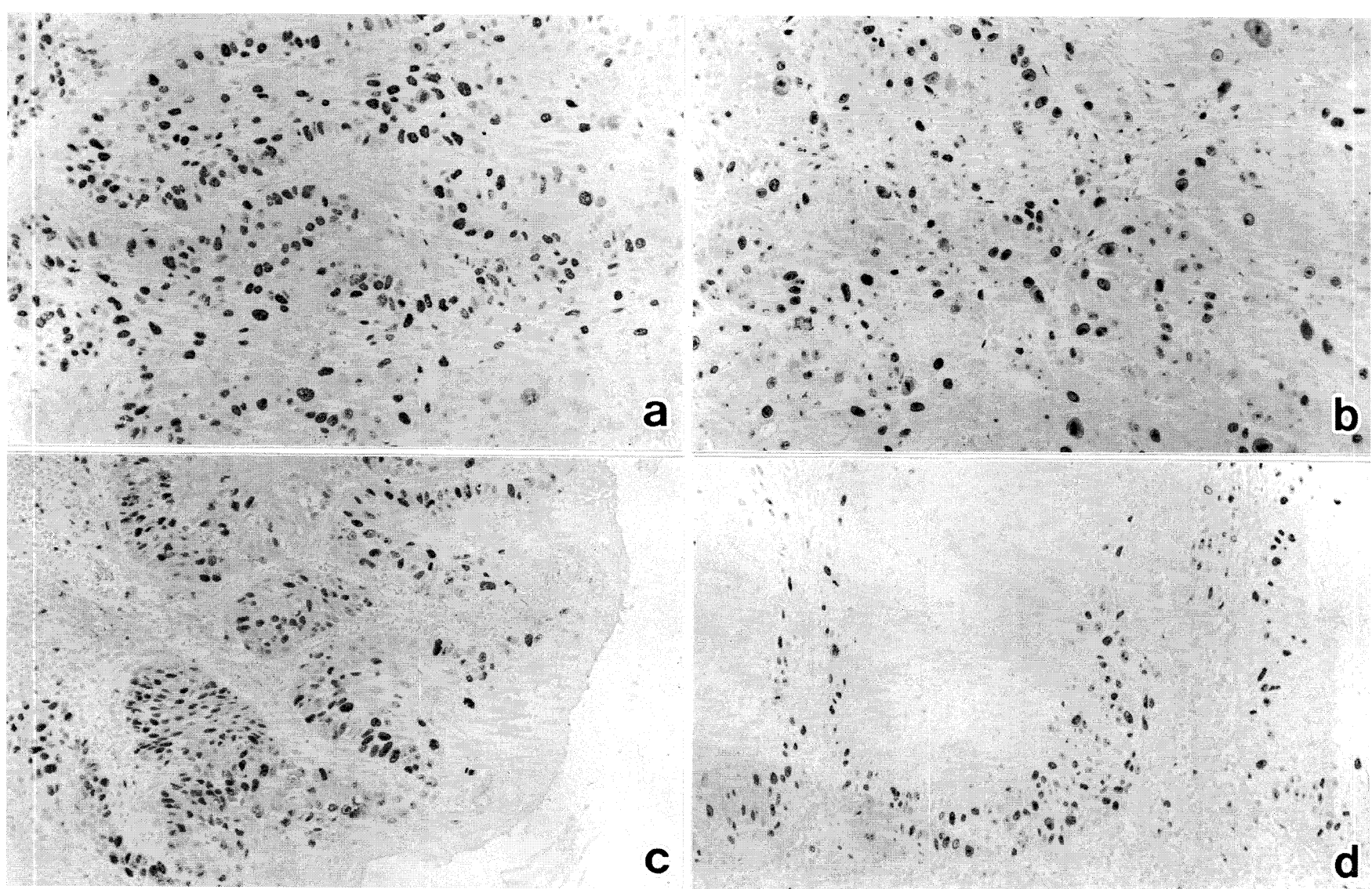

Fig. 3 Ki-67 immunostaining ( $\times 200)$. (a) Papillary squamous cell carcinoma. (b) Conventional well differentiated squamous cell carcinoma. (c) Microinvasive squamous cell carcinoma. (d) Verrucous carcinoma. 
been described in the literature, and such tumors are called hybrid carcinomas $(6,8)$. Ishiyama et al. suggested that these hybrid carcinomas are probably identical to PSCC (7).

The relationship of PSCC to HPV is unclear. Crissman et al. reported that all PSCCs were uniformly negative for HPV DNA by in situ hybridization (4), although HPV type 6 DNA was found by PCR in a single case reported by Judd et al (5).

The expression of cell cycle-associated proteins, especially Ki-67, has been well studied immunohistochemically in SCC, MSCC and VC of the head and neck (9-13), and the present results are very similar to those in previous reports. Ki-67 is a cellular proliferation marker expressed at all phases of the cell cycle except G0. Increased $\mathrm{Ki}-67$ expression has been reported to be a good indicator of cell proliferative activity in premalignant and malignant oral lesions $(9,11,13)$. In the present study, the mean percentage of Ki-67 expression was high in PSCC, SCC and MSCC, and there was no significant difference in expression among these lesions. On the other hand, the mean percentage of Ki-67 expression was significantly low in VC when compared to PSCC, SCC and MSCC.

Although the number of well documented cases is small, it is thought that the postoperative prognosis of PSCC is good, and that distant metastases are rare (6). Some authors believe that patients with PSCC at stage T3 or greater should undergo prophylactic neck dissection, in view of possible neck metastases (7), whereas others claim the biological behavior of PSCC with invasion appears to be analogous to that of SCC of equivalent stage $(3,4)$. The present two PSCCs, which were about $10 \mathrm{~mm}$ in greatest diameter, showed a significantly high mean percentage of Ki-67 expression compared with $\mathrm{VC}$, and there was no significant difference in Ki-67 expression among PSCC, SCC and MSCC. These results suggest that the biological behavior of PSCC with or without invasion into the underlying fibrous tissue appears to be analogous to that of SCC of equivalent stage.

\section{References}

1. Shanmugaratnam, K. and Sobin, L.H. (1991) Histological typing of tumours of the upper respiratory tract and ear. 2nd ed., Springer-Verlag, Berlin, 29-30

2. Pindborg, J.J., Reichart, P.A., Smith, C.J. and van der Waal, I. (1997) Histological typing of cancer and precancer of the oral mucosa. 2nd ed., SpringerVerlag, Berlin, 13

3. Mills, S.E., Gaffey, M.J. and Frierson, H.F. (2000) Tumors of the upper aerodigestive tract and ear. In
Atlas of tumor pathology. 3rd series, Fascicle 26, Armed Forces Institute of Pathology, Washington, D.C., $85-87$

4. Crissman, J.D., Kessis, T., Shah, K.V., Fu, Y.S., Stoler, M.H., Zarbo, R.J. and Weiss, M.A. (1988) Squamous papillary neoplasia of the adult upper aerodigestive tract. Hum. Pathol. 19, 1387-1396

5. Judd, R., Zaki, S.R., Coffield, L.M. and Evatt, B.L. (1991) Human papillomavirus type 6 detected by the polymerase chain reaction in invasive sinonasal papillary squamous cell carcinoma. Arch. Pathol. Lab. Med. 115, 1150-1153

6. Ferlito, A., Devaney, K.O., Rinaldo, A. and Putzi, M.J. (1999) Papillary squamous cell carcinoma versus verrucous squamous cell carcinoma of the head and neck. Ann. Otol. Rhinol. Laryngol. 108, 318-322

7. Ishiyama, A., Eversole, L.R., Ross, D.A., Raz, Y., Kerner, M.M., Fu, Y.S., Blackwell, K.E., Feneberg, R., Bell, T.S. and Calcaterra, T.C. (1994) Papillary squamous neoplasms of the head and neck. Laryngoscope 104, 1446-1452

8. Medina, J.E., Dichtel, W. and Luna, M.A. (1984) Verrucos-squamous carcinomas of the oral cavity. A clinicopathological study of 104 cases. Arch. Otolaryngol. 110, 437-440

9. Girod, S.C., Krueger, G. and Pape, H.D. (1993) P53 and Ki-67 expression in preneoplastic and neoplastic lesions of the oral mucosa. Int. J. Oral. Maxillofac. Surg. 22, 285-288

10. Zoeller, J., Flentje, M., Sinn, P. and Born, I.A. (1994) Evaluation of AgNOR and Ki-67 antigen as cell kinetic parameters in oral dysplasias and carcinomas. Anal. Cell. Pathol. 7, 77-88

11. Ichikawa, M., Ishii, K., Nakajima, T. and Mogi, K. (1997) The overexpression of p53 and proliferative activity in precancerous and cancerous lesions of oral squamous epithelium. J. Exp. Clin. Cancer Res. 16, 141-146

12. Nylander, K., Schildt, E.B., Eriksson, M. and Roos, G. (1997) PCNA, Ki-67, p53, bcl-2 and prognosis in intraoral squamous cell carcinoma of the head and neck. Anal. Cell. Pathol. 14, 101-110

13. Saito, T, Nakajima, T. and Mogi, K. (1999) Immunohistochemical analysis of cell cycleassociated proteins p16, pRb, p53, p27 and Ki-67 in oral cancer and precancer with special reference to verrucous carcinomas. J. Oral Pathol. Med. 28, 226-232 